\title{
Glycerol to Solketal for Fuel Additive: Recent Progress in Heterogeneous Catalysts
}

\author{
Is Fatimah ${ }^{1, *(\mathbb{D})}$, Imam Sahroni ${ }^{1}\left(\mathbb{D}\right.$, Ganjar Fadillah ${ }^{1}$, Muhammad Miqdam Musawwa ${ }^{1}$, \\ Teuku Meurah Indra Mahlia ${ }^{2}$ and Oki Muraza ${ }^{3, *}$ \\ 1 Department of Chemistry, Faculty of Mathematics and Natural Sciences, Universitas Islam Indonesia, \\ Jl. Kaliurang Km 14, Sleman, Yogyakarta 55584, Indonesia \\ 2 School of Information, Systems and Modelling, Faculty of Engineering and Information Technology, \\ University of Technology Sydney, Sydney, NSW 2007, Australia \\ 3 Center of Research Excellence in Nanotechnology and Chemical Engineering Department, \\ King Fahd University of Petroleum \& Minerals, Dhahran 31261, Saudi Arabia \\ * Correspondence: isfatimah@uii.ac.id (I.F.); omuraza@kfupm.edu.sa (O.M.)
}

Received: 4 June 2019; Accepted: 10 July 2019; Published: 25 July 2019

\begin{abstract}
Biodiesel has been successfully commercialized in numerous countries. Glycerol, as a byproduct in biodiesel production plant, has been explored recently for fuel additive production. One of the most prospective fuel additives is solketal, which is produced from glycerol and acetone via an acetalization reaction. This manuscript reviewed recent progress on heterogeneous catalysts used in the exploratory stage of glycerol conversion to solketal. The effects of acidity strength, hydrophobicity, confinement effect, and others are discussed to find the most critical parameters to design better catalysts for solketal production. Among the heterogeneous catalysts, resins, hierarchical zeolites, mesoporous silica materials, and clays have been explored as effective catalysts for acetalization of glycerol. Challenges with each popular catalytic material are elaborated. Future works on glycerol to solketal will be improved by considering the stability of the catalysts in the presence of water as a byproduct. The presence of water and salt in the feed is certainly destructive to the activity and the stability of the catalysts.
\end{abstract}

Keywords: fuel additives; biodiesel; glycerol; solketal; solid acid catalysts.

\section{Introduction}

The exploration of renewable energy to supplement limited fossil fuels in the next few years is one the most concerned research topics. Among some renewable energy resources, biofuels are receiving intensive attention, especially for some countries with a large production of vegetable oils and bio-oils for biodiesel production [1-4]. Annual production and consumption of biodiesel is likely to increase significantly in the coming few years. Numerous sources of abundant edible and potential non-edible oils have been identified [5]. Regardless, this fact leads to increasing glycerol production as the byproduct of biodiesel conversion [2]. Due to the chemical process of the biodiesel production, the molar ratio of glycerol to the methyl ester is $3: 1$, or about $10 \%$ to $20 \%$ of the total volume of biodiesel produced is made up of glycerol. The rapid growth of biodiesel production has contributed much to the increasing glycerol production since it was reported that the worldwide production of glycerol increased from 7.8 billion liters in 2006 to 36 billion liters in 2018 [6,7]. This fact revealed that glycerol is an abundant renewable chemical feedstock in the world. The conversion of glycerol into more valuable chemicals is the best option to create a new market for glycerol and improve the sustainability of biodiesel production [7-14]. 
This mini review paper aims to emphasize the potential exploration of catalytic materials for the conversion of glycerol to solketal by analyzing recent papers, especially open literature from after 2010. Rahmat et al. (2010) [15] wrote an overview of glycerol conversion to fuel additives, with an emphasis on reaction parameters (catalyst, reactant, temperature, and reaction time). In the range of 2009 to 2018, Cornejo et al. [16] wrote a review in 2017 on glycerol valorization to fuel additives over different co-reactants. These included second feeds, such as formaldehyde, acetaldehyde, butanal, and acetone, and many others. Nanda et al. [17] published a review on solketal as a fuel additive, with an emphasis on the historical and future context. This paper also summarized the effect of acidity, reactor models, kinetics and reactor kinetics, and the daily procedure to use glycerol to solketal.

Many scenarios were conducted for the conversion of glycerol to different value-added chemicals, such as propane-acrolein, 1, 3-diol, propane-1,2-diol, acetal or ketal, polyols and polyurethane foams, glycerol carbonate, etc. $[10,11,18]$. Table 1 shows that among these glycerol conversions, the conversion of glycerol to solketal by acetalization is an interesting route. Solketal is one of the glycerol acetalization products together with glycerol acetal and glycerol formal (GlyF). Similar to other acetalization products, solketal can be used directly as a fuel additive for the reduction of soot and gum formation [19]. Solketal addition to a gasoline blend showed better fuel properties with a higher octane number [19]. Other applications of solketal are in solvents, inks, pharmaceuticals, and paints [20].

Table 1. Different conversion routes from glycerol to value-added products.

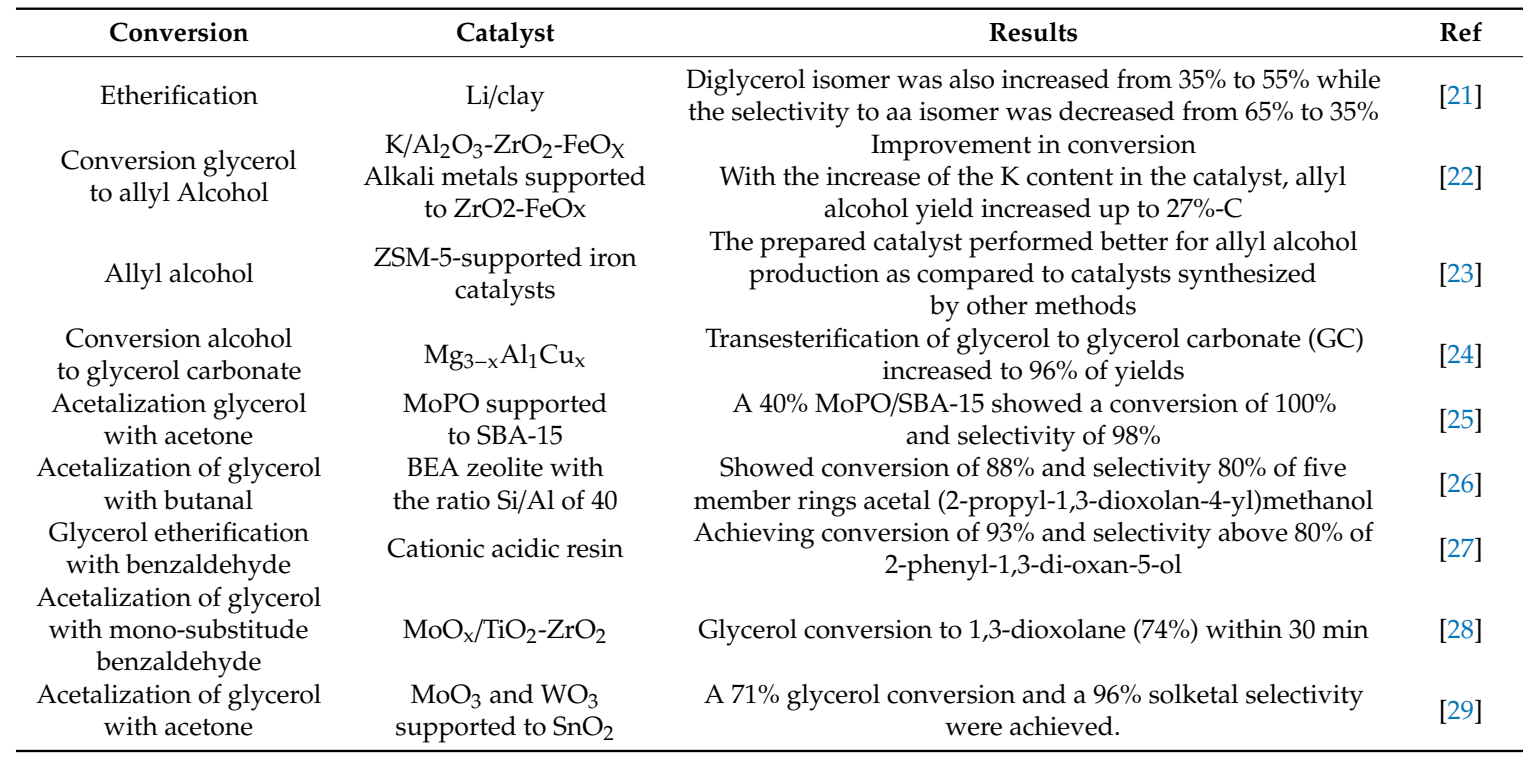

As shown in Table 2 and Figure 1, different types of catalyst materials were reported for the solketal production consisting of zeolites, clays, resins, heteropolyacids, and others. Each catalyst has both advantages and drawbacks. A homogeneous catalyst, such as $\mathrm{H}_{2} \mathrm{SO}_{4}$, offers high activity, however, these homogenous catalysts are corrosive, not recyclable, difficult to separate, and considerably more expensive. Similarly, chloride, such as tin chloride $\left(\mathrm{SnCl}_{2}\right)$, is also unwanted due to its corrosion tendency [30]. Reusability is also an important part of studies. Reusability is a factor which is studied as a typical sustainable principle. The basic mechanism of the metal salt catalysis is a nucleophilic attack by the hydroxyl group of glycerol to the carbocation obtained from the protonation step, resulting in the formation of the intermediate, followed by a water elimination step. The carbocation is produced from the Lewis or Brønsted acid sites, which activates the ketone carbonyl group through a protonation step (i.e., Brønsted acids) or polarization.

However, homogeneous catalysts are not considered as environmental-friendly for the reaction system. Another challenge in the utilization of heterogeneous catalysts in solketal production is 
the byproduct (water) formed during the reaction, which induces a reversible reaction. Heterogeneous catalysts are regenerated easily and are more easily handled. Many resin catalysts exhibited excellent conversion of glycerol to solketal and selectivity, where the best catalytic performance was obtained by amberlyst. However, it is not feasible for a higher scale of production due to the limitation of thermal stability, so it is not easy to regenerate. The higher thermal stability can be found in hierarchical zeolite. The highest conversion of glycerol to solketal of $72 \%$ and the selectivity of $72 \%$ are reached by using H-Beta (BEA framework) under the condition of $60{ }^{\circ} \mathrm{C}$, stirring at $700 \mathrm{rpm}, 5 \%$ of catalyst, and molar ratio of glycerol:acetone of 1:4 for H-BEA. Within the zeolite materials, MFI zeolite showed $80 \%$, which is a lower catalytic activity in comparison with amberlyst, but with almost $100 \%$ selectivity. The lower conversion is due to the relatively narrow channel size that affects the transport of the reactant carried out and the shape selectivity.

Table 2. Classification of heterogeneous catalysts for solketal production.

\begin{tabular}{cccccc}
\hline Others & Heteropolyacid & Resin & Meso-SiO & $\begin{array}{c}\text { Double Layer } \\
\text { Hydroxide and Clay }\end{array}$ & Zeolites \\
\hline Co/CNT & Si-W (tungstosilisic) & Amberlyst & KIT-6 & $\mathrm{ZrO}_{2}$ dolomite & Zeolite X \\
Na-lignosulfonate & HMQ-SJW & Cat. Ex. & Me-SBA-5J & Nb, AlOx & VnOx/FER MOR \\
SnF $_{2}$ & $\mathrm{H}_{3}$ PW12040 & Amberlyst-46 & Hf-SBA-15 & Nb oxy OH & BEA \\
Ionic liquid & & Amberlyst-46 & Mo-SBA-15 & COK-S & Hierarchical \\
Carbon & & KU-2-8 & Sn TUD-1 & MgLDH & BEA, MOR \\
& & Lewatit GF101 & Al-MCM-41 & Montmorillonite & ZSM-5 (MFI) \\
& & Sulfonic & Ga-MCM-4 & & DeAl BEA \\
& & & & Acidity BEA \\
\hline
\end{tabular}

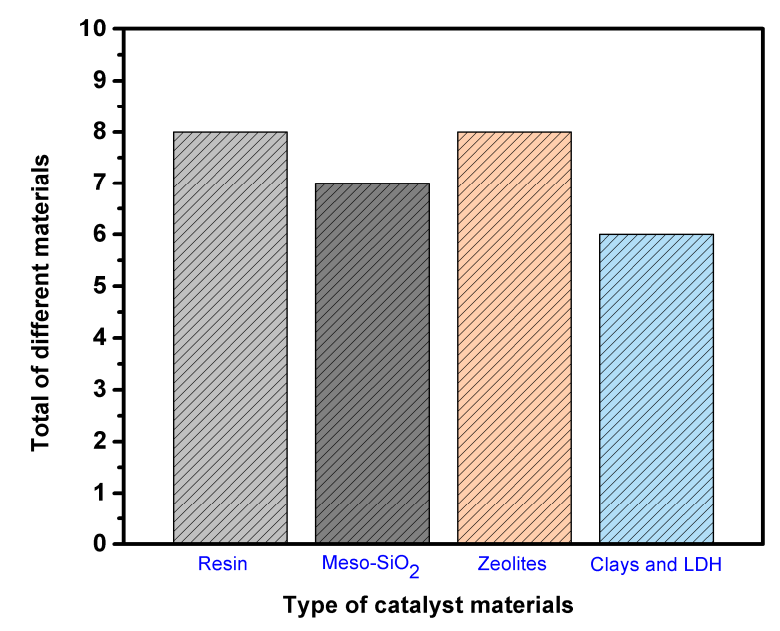

Figure 1. Popularity of different types of catalytic materials for solketal production from 2014 to 2018. (Source: Web of Knowledge, https://www.webofknowledge.com, November 2018).

\section{Glycerol-to-Solketal Over Resin Catalysts}

Overall, the most important properties of solid acid catalysts for the conversion glycerol to solketal production was the Brønsted acidity of solid acids [31]. The conversion of glycerol to solketal with resin catalysts has been carried out [32-36]. Table 3 summarizes the conversion of glycerol to solketal over resin catalysts. A typical resin catalyst (i.e., amberlyst) catalyzed the reaction of glycerol with acetone to produce above $80 \%$ of the glycerol conversion. Guidi et al. [36] reported that a resin, amberlyst-36, which was applied at different reaction temperatures from 25 to $70{ }^{\circ} \mathrm{C}$, was an excellent catalyst to convert glycerol with a conversion of $85 \%$ to $97 \%$ to solketal with a selectivity of $99 \%$. The catalyst is also active at lower pressures with similar reaction parameters either in pure glycerol or in an equimolar reactant. According to some references, the high conversion was influenced not only by the surface acidity but also by the resin structure. Moreover, the surface acidity was an important parameter that played a crucial role in improving the selectivity and the conversion in the production of solketal. 
Although amberlyst-46 and amberlyst-36 is a similar material, both types of resins have a different acid capacity and structure morphology. Furthermore, all resins showed good selectivity to solketal $(>80 \%)$, and the important catalytic parameter of the resin to conversion glycerol is the acid capacity (oversulfonated resin). With the highest acid capacity (sulfonic acid), these catalyst materials can improve not only the selectivity to solketal production but also the conversion of raw glycerol to above $90 \%$. Another important thing to be highlighted as a limitation of the catalyst activity is the presence of $\mathrm{NaCl}$ as a poison for the surface acidity, which is possibly due to the impurities in glycerol.

Table 3. Glycerol-to-solketal over resin catalysts.

\begin{tabular}{|c|c|c|c|c|c|c|}
\hline Source & Catalyst & Condition & Conversion & $\begin{array}{l}\text { Selectivity } \\
\text { to Solketal }\end{array}$ & Remark & Ref \\
\hline $\begin{array}{l}\text { Glycerol } \\
\text { and Acetone }\end{array}$ & Amberlyst-15 & $50^{\circ} \mathrm{C}$ & $92 \%$ & $96 \%$ & $\begin{array}{l}\text { Glycerol:acetone }=1: 2,7.0 \mathrm{~g} \text { of } \\
\text { amberlyst- } 15 \text { in } 96 \mathrm{~min}\end{array}$ & [32] \\
\hline $\begin{array}{l}\text { Glycerol } \\
\text { and Acetone }\end{array}$ & Amberlyst-46 & $60^{\circ} \mathrm{C}$ & $84 \%$ & $97 \%$ & $\% 1(\mathrm{w} / \mathrm{w})$ catalyst, $30 \mathrm{~min}$ & [33] \\
\hline $\begin{array}{l}\text { Glycerol } \\
\text { and Acetone }\end{array}$ & $\begin{array}{l}\text { Amberlyst } \\
\text { DPT-1 }\end{array}$ & $70^{\circ} \mathrm{C}$ & $97 \%$ & $98 \%$ & $\begin{array}{c}\text { Glycerol:acetone }=1: 2 \\
\text { at ambient pressure } \\
\text { Glycerol:acetone }=1: 20 \text { c catalyst }\end{array}$ & [34] \\
\hline $\begin{array}{l}\text { Glycerol } \\
\text { and Acetone }\end{array}$ & $\begin{array}{l}\text { DT-851 sulfonic } \\
\text { acid resin }\end{array}$ & $58^{\circ} \mathrm{C}$ & $95 \%$ & $99 \%$ & $\begin{array}{c}\text { DT- } 851 \text { sulfonic acid resin dosage } \\
\text { is } 5 \% \text { (wt., calculated by glycerol), } \\
\text { reaction time is } 2 \mathrm{~h} \text {. }\end{array}$ & [35] \\
\hline $\begin{array}{l}\text { Glycerol } \\
\text { and acetone }\end{array}$ & Amberlyst-36 & $25^{\circ} \mathrm{C}$ & $85 \%-97 \%$ & $99 \%$ & $\begin{array}{c}\text { At } 10 \text { barr and } 25^{\circ} \mathrm{C}, \mathrm{A} 36 \text { was } \\
\text { a highly active catalyst allowing } \\
\text { good-to-excellent conversion } \\
(85 \%-97 \%) \text { and selectivity }(99 \%) \\
\text { when either pure or wet glycerol } \\
\text { was used as a reagent. }\end{array}$ & [36] \\
\hline
\end{tabular}

Note: glycerol to the second reactant ratio was presented as molar ratio.

\section{Glycerol-to-Solketal over Mesoporous Silica}

Koranyi et al. [37] reported the superiority of hafnium and zirconium modified TUD-1 as superior catalysts for the conversion of glycerol to solketal. These two catalysts (Hf-TUD-1 and Zr-TUD-1) were more active than Sn-MCM-41 and Al-TUD-1. The Zr and Hf-TUD-1 are examples of active metal-modified mesoporous silica in which $\mathrm{Hf}$ and $\mathrm{Zr}$ are in the framework. Their activity was higher than FAU(USY) and Al(TUD-1). The highest conversion of glycerol to solketal was more than $50 \%$. The catalytic activity was a function of (i) the number of acid sites, (ii) the presence of mesopores, (iii) the existence of a large surface area, and (iv) the hydrophobicity of the catalyst [38]. The later, the hydrophobicity of the catalyst, was crucial to prevent the hydrolysis of solketal [37-41]. According to Table 4, Cs 2.5/KIT- 6 catalyst was one of the best catalysts for the conversion of glycero-to-solketal [42]. KIT- 6 was selected because of its large surface area $\left(600-1000 \mathrm{~m}^{2} / \mathrm{g}\right)$, active sites, and accessible pores [42].

Numerous references reported that mesoporous silica catalysts have the advantage of high stability in the conversion of glycerol to solketal, resulting in products with a relatively large percentage of conversion (95\%) and selectivity to solketal (98\%) [37,42-46]. The mesoporous structure with an activated surface by sulfonic acid might be applied efficiently for the conversion of glycerol to fuel additive $[37,43,47]$. A sulfonic acid-functionalized mesoporous polymer $\left(\mathrm{MP}-\mathrm{SO}_{3} \mathrm{H}\right)$ contains a high acidity surface $(1.88 \mathrm{mmol} / \mathrm{g})$. The surface acidity of catalytic materials can accelerate the formation products of solketal via ketalization reactions as shown in Figure 2. 
Table 4. Glycerol-to-solketal over mesoporous silica.

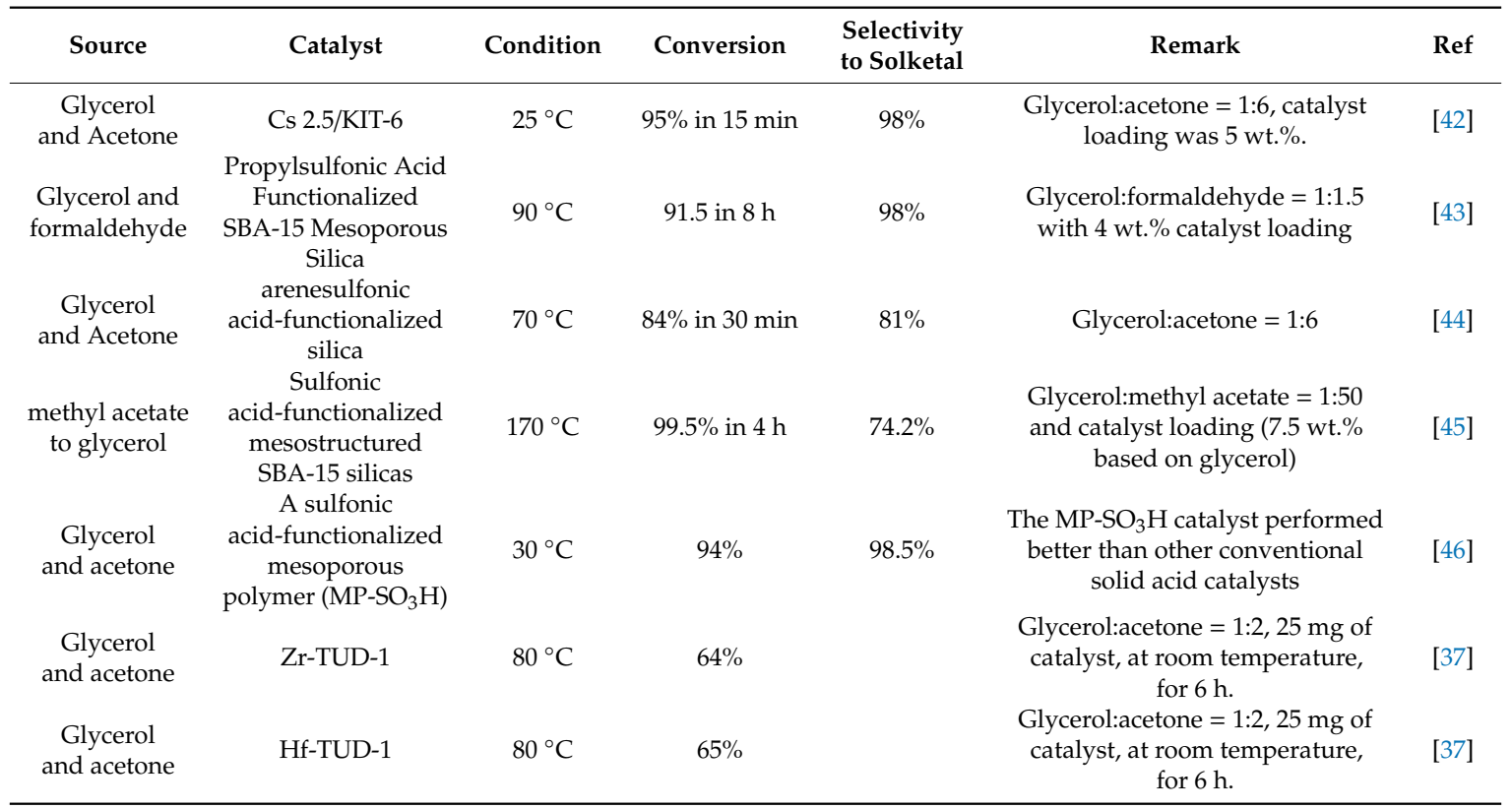

Note: glycerol to the second reactant ratio was presented as molar ratio.

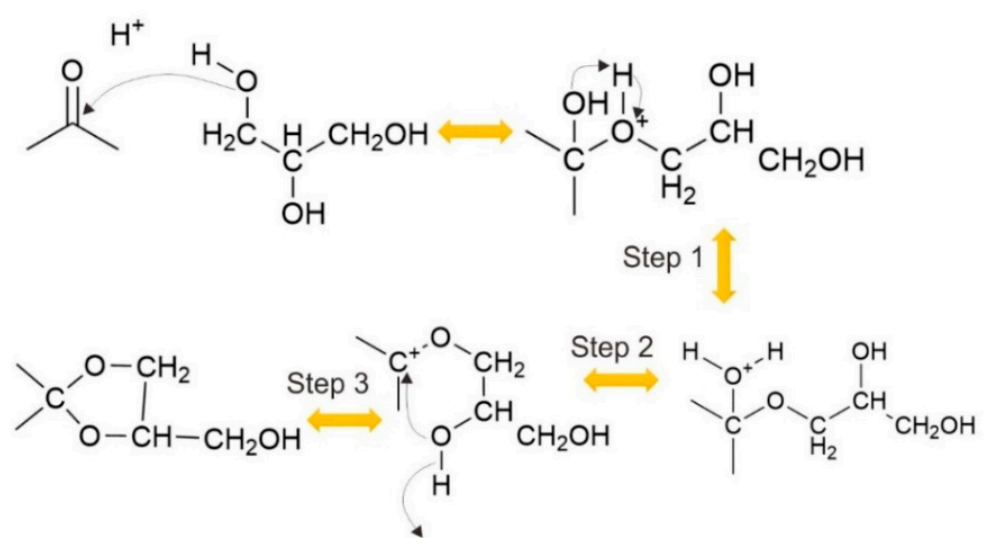

Figure 2. Scheme of mechanism for the ketalization reaction of glycerol and acetone.

\section{Ketalization of Glycerol over Clay Minerals}

Malaya et al. $[17,48]$ studied different clay-based catalysts with different acid strengths ranging from 0.12 to $5.7 \mathrm{meq} / \mathrm{g}$ [17]. The results show that a stronger acidity improved the conversion of glycerol up to ca. $80 \%$. As shown in Table 5, solketal production from glycerol used two different sources, namely acetone or formaldehyde over solid acid catalysts [49-52]. Based on the conversion of glycerol and selectivity to solketal, the clay catalyst which showed the optimum results was reported by Timofeeva et al. in a batch reactor with activated catalyst by nitric acid of $0.5 \mathrm{M}$ [53]. In the activated K10 montmorillonite by acid solution, this impact causes an increasing rate of reaction with the acid site of the material. It is well-known that the acid activation of natural montmorillonite with nitric acid can change the structure of montmorillonite (leaching of $\mathrm{Al}^{3+}$ cations from the octahedral to increase the surface area and microporosity of catalyst materials) [54-56]. The reaction of solketal production is shown in Figure 3. The use of formaldehyde as the major source of solketal production has a lower conversion value (only $83 \%$ glycerol conversion), with the K10 montmorillonite used as a catalyst. It may be due to the formation of the hemiacetal or hemicetal via two different pathways. The reaction between glycerol and acetone is preferred as it produces a more stable intermediate, 
hemicetal compound, with a tertiary carbenium ion [37]. While, in the reaction between glycerol with formaldehyde, the produced hemiacetal formation is not a stable carbenium ion. Thus, the conversion value for the glycerol-formaldehyde system is relatively small as compared to the reaction where acetone is used as a co-reactant [57-59].

Table 5. Glycerol-to-solketal over clay minerals.

\begin{tabular}{|c|c|c|c|c|c|c|}
\hline Source & Catalyst & Condition & Conversion & $\begin{array}{l}\text { Selectivity } \\
\text { to Solketal }\end{array}$ & Remark & Ref \\
\hline $\begin{array}{l}\text { Glycerol } \\
\text { and acetone }\end{array}$ & $\begin{array}{l}\text { Montmorilonite } \\
\text { modified by } \\
\mathrm{HNO}_{3}\end{array}$ & $\mathrm{~T}=25^{\circ} \mathrm{C}$ & $94 \%$ & $95.4 \%$ & $\begin{array}{l}\text { Glycerol:acetone }=1: 4,10 \mathrm{mg} \text { of } \\
\text { catalyst, time at } 10 \mathrm{~min}\end{array}$ & [53] \\
\hline $\begin{array}{l}\text { Glycerol and } \\
\text { benzaldehyde }\end{array}$ & $\begin{array}{c}\text { K10 } \\
\text { Montmorillonite }\end{array}$ & $\mathrm{T}=40{ }^{\circ} \mathrm{C}$ & $83 \%$ & $99 \%$ & $\begin{array}{l}\text { Glycerol:benzaldehyde dimethyl } \\
\text { acetal = 1:1.1 at } 6 \mathrm{~h} \text {. }\end{array}$ & [17] \\
\hline $\begin{array}{l}\text { Glycerol } \\
\text { and acetone }\end{array}$ & K10 clays & $\mathrm{T}=30^{\circ} \mathrm{C}$ & $87 \%$ & $85 \%$ & $\begin{array}{l}\text { Glycerol:acetone }=1: 6, \\
\text { catalyst loading was } 3 \mathrm{wt} . \% \text { of total } \\
\text { reactant weight, time at } 120 \mathrm{~min}\end{array}$ & [60] \\
\hline $\begin{array}{l}\text { Glycerol and } \\
\text { formaldehyde }\end{array}$ & $\begin{array}{c}\text { K10 } \\
\text { Montmorillonite }\end{array}$ & $\mathrm{T}=70^{\circ} \mathrm{C}$ & $80 \%$ & - & Glycerol: formaldehyde = 1:1.2 & [61] \\
\hline $\begin{array}{l}\text { Glycerol } \\
\text { and acetone }\end{array}$ & $\begin{array}{c}\text { K10 } \\
\text { Montmorillonite }\end{array}$ & $\mathrm{T}=40^{\circ} \mathrm{C}$ & $69 \%$ & $68 \%$ & $\begin{array}{c}\text { Glycerol:acetone }=2: 6, \mathrm{P}=600 \mathrm{psi} \text {, } \\
\text { The amount of catalyst in each run } \\
\text { was determined by the selected } \\
\text { weight hourly space velocity } \\
\left(\text { WHSV) at } 4 \mathrm{~h}^{-1}\right.\end{array}$ & [48] \\
\hline
\end{tabular}

Note: glycerol to the second reactant ratio was presented as a molar ratio.

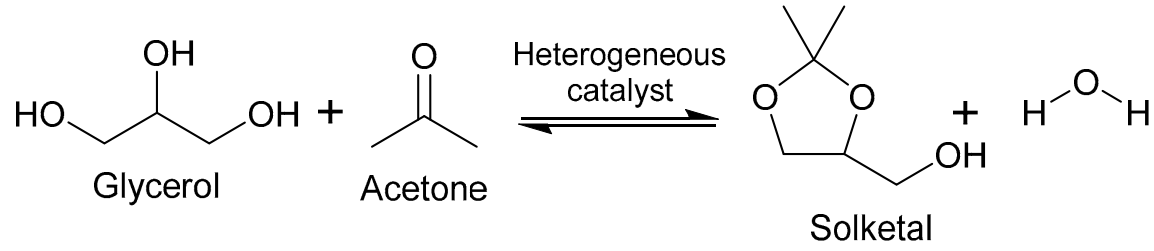

Figure 3. Synthesis scheme of glycerol to solketal.

Koranyi et al. (2012) [37] reported the effect of water as an impurity in the acetalization of glycerol. The presence of water reduced the activity ca. 50\% lower than the one with the model compound (pure glycerol). A high number of Brønsted and Lewis sites does not correspond directly to a high activity. Dealumination FAU and Al-TUD-1 with a high Brønsted and Lewis acidity were poor in the acetalization of glycerol [37]. Hydrophobic catalysts, such as hafnium and TUD-1 zirconium on TUD-1, are very prospective for glycerol to solketal. Ammaji et al. (2017) [62] also reported a similar observation, as the Zr-SBA-15 was the most active and selective catalyst.

\section{Perspective on Ketalization of Glycerol over Hierarchical Zeolites}

Dmitriev et al. (2016) [63] reported that zeolite beta was the most active solid acid catalyst as compared to amberlist-35 and cation-exchange resin (KU-2-8) [62]. The zeolite beta applied was a commercial one from zeolyst with $\mathrm{SiO}_{2} / \mathrm{Al}_{2} \mathrm{O}_{3}$ of 25 and a zeolite beta made by Angarsk. Kowalska et al. $[64,65]$ studied the effect of (i) different zeolite topologies (MFI, BEA, and MOR), (ii) Si/Al ratio from 9.2 to 25.8 , and (iii) mesoporosity. Two parent MFI zeolites with different Si/Al were applied $(\mathrm{Si} / \mathrm{Al}=12$ and $\mathrm{Si} / \mathrm{Al}=27)$ [64]. The hierarchical zeolites were obtained by desilication using $0.2 \mathrm{M} \mathrm{NaOH}$ and dealumination using citric acid $(0.5 \mathrm{M})$ and nitric acid $(0.5 \mathrm{M})$. The diffusion limitation of the parent zeolites was considered as the highest activity of the parent MFI was significantly lower than the one from the hierarchical MFI. A high selectivity (up to 100\%) to solketal was obtained with an acetone:glycerol ratio of 1 . A higher acetone to glycerol ratio was obtained over a higher acetone to glycerol ratio. Both desilication and dealumination are very effective in improving the catalyst stability of zeolite based catalyst [66-68]. 
Rossa et al. [69] conducted the kinetics study of acetalization of glycerol with acetone to produce solketal with optimization of the kinetics parameters. Zeolite beta with an Si/Al of 19 was applied to find the best parameters: (i) External mass transfer (stirring rate), (ii) temperature, (iii) catalyst amount, and (iv) glycerol to acetone ratio. The targeted goals were glycerol conversion and solketal selectivity. The experimental design for beta zeolite showed that the suggested reaction parameters are: Temperature at $60{ }^{\circ} \mathrm{C}$, stirring rate of $700 \mathrm{rpm}$, catalyst loading of $5 \%$, and glycerol to acetone ratio of 1:3. A higher acetone content will increase the conversion of glycerol [24,70]. However, an increase of the acetone to glycerol ratio will increase the exergy destruction rate due to a reduction in the rate of formation toward the product and a higher consumption of electrical exergy to the acetalization reactor $[20,71-80]$.

Hierarchical zeolite shows excellent glycerol conversion and selectivity to solketal through acetalization reactions. The catalytic materials show a higher glycerol conversion (until more than an $80 \%$ glycerol conversion) as compared to other porous and non-porous catalysts due to a large pore size and easy molecular diffusivity. The enhancement of the catalytic activity of zeolites in glycerol acetalization, through the generation of a hierarchical porosity, has been applied by different authors as shown in Table 6. Based on the literature, the crystallite size was one of the most determining factors in the activity of hierarchical zeolite as a catalyst [64,81-85]. The smaller the crystal size of zeolite, the easier the diffusion of the reactant and products though the zeolite pores $[73,86,87]$. The pore structure of the zeolite can be changed through the dealumination and desilication processes. The process not only can change the mesopore materials but also can increase the catalytic activity (improving the accessibility and mass transfer on the surface) [88]. Hierarchical zeolites with different topologies, such as ZSM-5 (MFI) [67,89,90], beta (BEA) [81,91,92], and Y (FAU) [64], have also been used in the acetalization of glycerol, and the results show that smaller pores can produce high glycerol conversion and selectivity to selectivity (almost 100\% selective for solketal formation). However, overall, all materials displayed very good catalytic performance when reacting equimolar mixtures of glycerol and acetone $[37,39]$. From the experiments on H-beta zeolite, it was found that dealumination resulted in a decrease of strong acid sites, thus decreasing the catalytic activity.

Table 6. Glycerol-to-solketal over hierarchical zeolite catalysts.

\begin{tabular}{|c|c|c|c|c|c|c|}
\hline Source & Catalyst & Condition & Conversion & $\begin{array}{l}\text { Selectivity } \\
\text { to Solketal }\end{array}$ & Remark & Ref \\
\hline $\begin{array}{c}\text { Glycerol } \\
\text { and acetone }\end{array}$ & $\begin{array}{c}\text { hierarchical } \\
\text { (micro-mesoporous) } \\
\text { MFI zeolites } \\
\text { (pore diameter } \\
0.51-0.55 \mathrm{~nm} \text { ) }\end{array}$ & $\mathrm{T}=70^{\circ} \mathrm{C}$ & $80 \%$ & $100 \%$ & $\begin{array}{c}\text { Glycerol:acetone }=1: 1, \text { catalyst in } \\
\text { the amount of } 1 \% \text { related } \\
\text { to glycerol. }\end{array}$ & [64] \\
\hline $\begin{array}{c}\text { Glycerol } \\
\text { and acetone }\end{array}$ & H-B-1 zeolites & $\begin{array}{c}\mathrm{T}=28^{\circ} \mathrm{C} \\
\text { (room temperature) }\end{array}$ & $86 \%$ & $98.5 \%$ & $\begin{array}{c}\text { Glycerol:acetone }=1: 2, \text { catalyst } \\
\text { amount }=5 \mathrm{wt} . \% \text { referred to } \\
\text { glycerol in } 1 \mathrm{~h} .\end{array}$ & [73] \\
\hline $\begin{array}{c}\text { Glycerol } \\
\text { and acetone }\end{array}$ & $\begin{array}{l}\text { Dealumination of } \\
\text { BEA Zeolites }\end{array}$ & $\mathrm{T}=30^{\circ} \mathrm{C}$ & $80 \%$ & $100 \%$ & $\begin{array}{l}\text { Glycerol:acetone }=1: 1, \mathrm{t}=30 \mathrm{~min}, \\
\text { catalyst loading was } 0.5 \mathrm{~g}\end{array}$ & [72] \\
\hline $\begin{array}{c}\text { Glycerol } \\
\text { and acetone }\end{array}$ & $\begin{array}{l}\text { H-Zeolite (pore size } \\
4.10 \mathrm{~nm} \text { ) }\end{array}$ & $\mathrm{T}=70^{\circ} \mathrm{C}$ & $75 \%$ & $92 \%$ & $\begin{array}{l}\text { Glycerol:acetone }=1: 3 \text { were used } \\
\text { with } 0.05 \mathrm{~g} \text { of catalyst for } 2 \mathrm{~h}\end{array}$ & [65] \\
\hline $\begin{array}{l}\text { Glycerol } \\
\text { and acetone }\end{array}$ & H-BEA Zeolite & $\mathrm{T}=60^{\circ} \mathrm{C}$ & $70 \%$ & $97.9 \%$ & $\begin{array}{c}\text { Glycerol:acetone }=1: 4 \text {, catalyst } \\
\text { amount was loading at } 5 \mathrm{wt} . \% \\
\text { for } 1 \mathrm{~h} .\end{array}$ & [69] \\
\hline
\end{tabular}

\section{Solketal Synthesis over Carbon/Activated Carbon-Based Catalyst}

Considering the abundant source of biomass as carbon and activated-carbon precursor, activated carbons were functionalized with acid groups for solketal synthesis [93,94]. Some papers showed the excellent performance of activated carbon for catalyzing the conversion of glycerol to solketal (Table 7) and some of these exhibited a high activity and selectivity under green conditions (solvent-free conditions at a mild temperature). The high surface area of activated carbon preserves the higher surface acid sites by some modification, including acid, metal, and composite modifications [24,95-97]. Therefore, they are promising candidates as heterogeneous catalysts for the acetalization of acetone with 
glycerol. From the utilization of acid functionalized activated carbon, the superior catalytic activity of the four acid-treated carbons was underlined as compared to the untreated activated carbon, confirming the importance of the higher number and strength of acid sites generated by the acid treatments. The catalysts were prepared by $\mathrm{HNO}_{3}$ and $\mathrm{H}_{2} \mathrm{SO}_{4}$ treatment to activated carbon. The catalytic activity of the catalyst showed excellent performance due to the high conversion and selectivity at room temperature.

Table 7. Glycerol-to-solketal over carbon/activated carbon-based catalyst.

\begin{tabular}{|c|c|c|c|c|c|c|}
\hline Source & Catalyst & Condition & Conversion & $\begin{array}{l}\text { Selectivity } \\
\text { to Solketal }\end{array}$ & Remark & Ref \\
\hline $\begin{array}{c}\text { acetone } \\
\text { and glycerol }\end{array}$ & $\begin{array}{c}\text { acid } \\
\text { functionalized } \\
\text { activated carbon }\end{array}$ & $\begin{array}{c}\text { Room } \\
\text { temperature, } \\
\text { glycerol to acetone } \\
\text { molar ratio of } 1: 4\end{array}$ & $97 \%$ & $96 \%$ & $\begin{array}{l}\text { The highest number and strength } \\
\text { of acid sites generated by the acid } \\
\text { treatments onto activated carbon } \\
\text { gave better yield and selectivity }\end{array}$ & [39] \\
\hline $\begin{array}{l}\text { glycerol with } \\
\text { benzaldehyde at }\end{array}$ & Graphene & $100^{\circ} \mathrm{C}$ and $120^{\circ} \mathrm{C}$ & $97 \%$ & & $\begin{array}{l}\text { Graphene catalyst produced } 76 \% \\
\text { yield at } 100{ }^{\circ} \mathrm{C} \text { and } 85 \% \text { yield } \\
\text { at } 120{ }^{\circ} \mathrm{C} \text {, selectivity } 100 \%\end{array}$ & [98] \\
\hline $\begin{array}{c}\text { acetone } \\
\text { and glycerol }\end{array}$ & $\begin{array}{l}\text { sulfonated } \\
\text { carbon-silica-meso } \\
\text { composite } \\
\text { materials }\end{array}$ & $\begin{array}{c}\text { acetone } \\
\text { and glycerol } \\
\text { molar ratio of } 1: 6, \\
\text { re- fluxed at } 70^{\circ} \mathrm{C}\end{array}$ & $82 \%$ & $99 \%$ & & [99] \\
\hline $\begin{array}{c}\text { acetone } \\
\text { and glycerol }\end{array}$ & $\begin{array}{c}\text { acidic } \\
\text { carbon-based } \\
\text { catalysts }\end{array}$ & & $80 \%$ & $95 \%$ & & [93] \\
\hline $\begin{array}{c}\text { acetone } \\
\text { and glycerol }\end{array}$ & $\begin{array}{l}\mathrm{Ni}-\mathrm{Zr} \text { supported } \\
\text { on mesoporous } \\
\text { activated carbon }\end{array}$ & $\begin{array}{c}\text { Room } \\
\text { Temperature } \\
\text { glycerol/acetone } \\
\text { ratio of } 1: 10\end{array}$ & $75 \%$ & $100 \%$ & $\begin{array}{l}\text { Conversion and selectivity are } \\
\text { affected by glycerol/acetone ratio } \\
\text { and temperature }\end{array}$ & [100] \\
\hline
\end{tabular}

From the acid-modified carbon catalyst, it was found that the presence of acid groups, mainly sulfonic groups, was the key factor for the improved catalytic performance. A similar pattern also appeared from the Ni-Zr support on the activated carbon [100], in which the active metal contributes by enhancing the catalyst acidity. Another factor affecting the catalytic activity was the higher total acid density, the large mesopore of the carbon structure, and the activity of the metals.

\section{Perspective and Conclusions}

This mini review highlighted the recent development on solid catalysts for the conversion of glycerol-to-solketal. The product is an additive for fuels, which are very useful to reduce GHGs and to improve the economic viability of biodiesel business [6,8,16,20,34,101-105]. Tailor-made heterogeneous catalyst for an optimal conversion of glycerol is developed and required. Five major heterogeneous catalysts were emphasized in this study: Resins, mesoporous silica, zeolites, clays, and activated carbons. The stability of catalysts is one of the main hurdles for the commercialization of glycerol to solketal. Even though the reaction temperature was considered as mild, the stability of most of the solid catalysts decayed in the presence of water as a byproduct and other impurities $(\mathrm{NaCl}$, methanol) from the glycerol source. The deactivation rate is even higher when the raw glycerol (contaminated with water) was fed to the reactor [106-109]. Therefore, the viability of the commercial plant depends on (i) the source of feeds [110], (ii) availability of glycerol and other feeds, and (iii) cost of glycerol as the feed. In general, at least three main challenges were identified:

a. The presence of water and impurities in the feed.

b. The shift from the batch reactor to the fixed bed reactor.

c. The presence of equilibrium offers other difficulties as higher acetone demand is expected. However, higher acetone to glycerol will lead to destructive instruments.

Acidity is agreed as an important properties of zeolite catalysts for glycerol to solketal. Strong acidity and medium hydrophobicity were expected in the design of the reactor. Based on some limitations of the catalyst performance, the utilization of raw glycerol directly will reduce 
the stability of the catalyst. This review described how a better material should be designed for the optimum conversion of glycerol (and generally polyol) to solketal. Hydrophobic catalysts, such as hafnium/TUD-1 and zirconium/TUD-1, are very prospective for glycerol to solketal. Extended works on low aluminum mesoporous silica materials are expected in the coming years.

Author Contributions: I.F. and O.M. contribute to design and conception, drafting the article, and final approval of the article. I.S., M.M.M., and G.F. contribute to collect the references, drafting the article, preparing all figures and all tables, and discussion. T.M.I.M. contributes to help data analysis and discussion.

Funding: This research was funded by Ministry of Research, Technology and Higher Education (KEMENRISTEKDIKTI) Republic of Indonesia through World Class Professor program in 2018, grant number: 123.6/D2.3/KP/2018. The APC was funded by the University of Technology Sydney seed fund (Org Unit 321740) with Account number (2232397).

Acknowledgments: Authors would like to express appreciation for the support from Ministry of Research, Technology and Higher Education (KEMENRISTEKDIKTI) Republic of Indonesia through World Class Professor program in 2018, grant number: 123.6/D2.3/KP/2018. The authors are thankful to Professor Paolo Pescarmona from University of Groningen for his rich suggestions on prospective catalytic materials in glycerol to solketal.

Conflicts of Interest: The authors declare no conflict of interest.

\section{References}

1. Silitonga, A.S.; Atabani, A.E.; Mahlia, T.M.I.; Masjuki, H.H.; Badruddin, I.A.; Mekhilef, S. A review on prospect of Jatropha curcas for biodiesel in Indonesia. Renew. Sustain. Energy Rev. 2011, 15, 3733-3756. [CrossRef]

2. Ong, H.C.; Masjuki, H.H.; Mahlia, T.M.I.; Silitonga, A.S.; Chong, W.T.; Leong, K.Y. Optimization of biodiesel production and engine performance from high free fatty acid Calophyllum inophyllum oil in CI diesel engine. Energy Convers. Manag. 2014, 81, 30-40. [CrossRef]

3. Galadima, A.; Muraza, O. Hydrothermal liquefaction of algae and bio-oil upgrading into liquid fuels: Role of heterogeneous catalysts. Renew. Sustain. Energy Rev. 2018, 81, 1037-1048. [CrossRef]

4. Galadima, A.; Muraza, O. Biodiesel production from algae by using heterogeneous catalysts: A critical review. Energy 2014, 78, 72-83. [CrossRef]

5. Silitonga, A.S.; Masjuki, H.H.; Ong, H.C.; Sebayang, A.H.; Dharma, S.; Kusumo, F.; Siswantoro, J.; Milano, J.; Daud, K.; Mahlia, T.M.I.; et al. Evaluation of the engine performance and exhaust emissions of biodiesel-bioethanol-diesel blends using kernel-based extreme learning machine. Energy 2018, 159, 1075-1087. [CrossRef]

6. Quispe, C.A.G.; Coronado, C.J.R.; Carvalho, J.A., Jr. Glycerol: Production, consumption, prices, characterization and new trends in combustion. Renew. Sustain. Energy Rev. 2013, 27, 475-493. [CrossRef]

7. Monteiro, M.R.; Kugelmeier, C.L.; Pinheiro, R.S.; Batalha, M.O.; Da Silva César, A. Glycerol from biodiesel production: Technological paths for sustainability. Renew. Sustain. Energy Rev. 2018, 88, 109-122. [CrossRef]

8. Dharma, S.; Masjuki, H.H.; Ong, H.C.; Sebayang, A.H.; Silitonga, A.S.; Kusumo, F.; Mahlia, T.M.I. Optimization of biodiesel production process for mixed Jatropha curcas-Ceiba pentandra biodiesel using response surface methodology. Energy Convers. Manage. 2016, 115, 178-190. [CrossRef]

9. Zakaria, Z.Y.; Linnekoski, J.; Amin, N.A.S. Catalyst screening for conversion of glycerol to light olefins. Chem. Eng. J. 2012, 207, 803-813. [CrossRef]

10. Galadima, A.; Muraza, O. A review on glycerol valorization to acrolein over solid acid catalysts. J. Taiwan Inst. Chem. Eng. 2016, 67, 29-44. [CrossRef]

11. Galadima, A.; Muraza, O. Sustainable Production of Glycerol Carbonate from By-product in Biodiesel Plant. Waste Biomass Valorization 2016, 8, 141-152. [CrossRef]

12. Bagheri, S.; Julkapli, N.M.; Yehye, W.A. Catalytic conversion of biodiesel derived raw glycerol to value added products. Renew. Sustain. Energy Rev. 2015, 41, 113-127. [CrossRef]

13. Rodrigues, A.; Bordado, J.C.; Santos, R.G.D. Upgrading the Glycerol from Biodiesel Production as a Source of Energy Carriers and Chemicals-A Technological Review for Three Chemical Pathways. Energies 2017, 10, 1817. [CrossRef] 
14. Smith, P.J.; Smith, L.; Dummer, N.F.; Douthwaite, M.; Willock, D.J.; Howard, M.; Knight, D.W.; Taylor, S.H.; Hutchings, G.J. Investigating the Influence of Reaction Conditions and the Properties of Ceria for the Valorisation of Glycerol. Energies 2019, 12, 1359. [CrossRef]

15. Rahmat, N.; Abdullah, A.Z.; Mohamed, A.R. Recent progress on innovative and potential technologies for glycerol transformation into fuel additives: A critical review. Renew. Sustain. Energy Rev. 2010, 14, 987-1000. [CrossRef]

16. Cornejo, A.; Barrio, I.; Campoy, M.; Lázaro, J.; Navarrete, B. Oxygenated fuel additives from glycerol valorization. Main production pathways and effects on fuel properties and engine performance: A critical review. Renew. Sustain. Energy Rev. 2017, 79, 1400-1413. [CrossRef]

17. Nanda, M.R.; Zhang, Y.; Yuan, Z.; Qin, W.; Ghaziaskar, H.S.; Xu, C. Catalytic conversion of glycerol for sustainable production of solketal as a fuel additive: A review. Renew. Sustain. Energy Rev. 2016, 56, 1022-1031. [CrossRef]

18. Mahdi, H.I.; Irawan, E.; Nuryoto, N.; Jayanudin, J.; Sulistyo, H.; Sediawan, W.B.; Muraza, O. Glycerol Carbonate Production from Biodiesel Waste Over Modified Natural Clinoptilolite. Waste Biomass Valorization 2016, 7, 1349-1356. [CrossRef]

19. Alptekin, E.; Canakci, M. Performance and emission characteristics of solketal-gasoline fuel blend in a vehicle with spark ignition engine. Appl. Therm. Eng. 2017, 124, 504-509. [CrossRef]

20. Aghbashlo, M.; Hosseinpour, S.; Tabatabaei, M.; Rastegari, H.; Ghaziaskar, H.S. Multi-objective exergoeconomic and exergoenvironmental optimization of continuous synthesis of solketal through glycerol ketalization with acetone in the presence of ethanol as co-solvent. Renew. Energy 2019, 130, 735-748. [CrossRef]

21. Ayoub, M.; Abdullah, A.Z. Diglycerol synthesis via solvent-free selective glycerol etherification process over lithium-modified clay catalyst. Chem. Eng. J. 2013, 225, 784-789. [CrossRef]

22. Konaka, A.; Tago, T.; Yoshikawa, T.; Shitara, H.; Nakasaka, Y.; Masuda, T. Conversion of Biodiesel-Derived Crude Glycerol into Useful Chemicals over a Zirconia-Iron Oxide Catalyst. Ind. Eng. Chem. Res. 2013, 52, 15509-15515. [CrossRef]

23. Sánchez, G.; Dlugogorski, B.Z.; Kennedy, E.M.; Stockenhuber, M. Zeolite-supported iron catalysts for allyl alcohol synthesis from glycerol. Appl. Catal. A Gen. 2016, 509, 130-142. [CrossRef]

24. Manikandan, M.; Prabu, M.; Sk, A.K.; Sangeetha, P.; Vijayaraghavan, R. Tuning the basicity of Cu-based mixed oxide catalysts towards the efficient conversion of glycerol to glycerol carbonate. Mol. Catal. 2018, 460, 53-62. [CrossRef]

25. Gadamsetti, S.; Rajan, N.P.; Rao, G.S.; Chary, K.V.R. Acetalization of glycerol with acetone to bio fuel additives over supported molybdenum phosphate catalysts. J. Mol. Catal. A Chem. 2015, 410, 49-57. [CrossRef]

26. Serafim, H.; Fonseca, I.M.; Ramos, A.M.; Vital, J.; Castanheiro, J.E. Valorization of glycerol into fuel additives over zeolites as catalysts. Chem. Eng. J. 2011, 178, 291-296. [CrossRef]

27. Yamamoto, K.; Kiyan, A.M.; Bagio, J.C.; Rossi, K.A.B.; Delabio Berezuk, F.; Berezuk, M.E. Green cyclic acetals production by glycerol etherification reaction with benzaldehyde using cationic acidic resin. Green Process. Synth. 2019, 8, 183-190. [CrossRef]

28. Sudarsanam, P.; Mallesham, B.; Prasad, A.N.; Reddy, P.S.; Reddy, B.M. Synthesis of bio-additive fuels from acetalization of glycerol with benzaldehyde over molybdenum promoted green solid acid catalysts. Fuel Process. Technol. 2013, 106, 539-545. [CrossRef]

29. Mallesham, B.; Sudarsanam, P.; Raju, G.; Reddy, B.M. Design of highly efficient Mo and W-promoted $\mathrm{SnO}_{2}$ solid acids for heterogeneous catalysis: Acetalization of bio-glycerol. Green Chem. 2013, 15, 478-489. [CrossRef]

30. Manjunathan, P.; Marakatti, V.S.; Chandra, P.; Kulal, A.B.; Umbarkar, S.B.; Ravishankar, R.; Shanbhag, G.V. Mesoporous tin oxide: An efficient catalyst with versatile applications in acid and oxidation catalysis. Catal. Today 2018, 309, 61-76. [CrossRef]

31. Stawicka, K.; Díaz-Álvarez, A.E.; Calvino-Casilda, V.; Trejda, M.; Bañares, M.A.; Ziolek, M. The Role of Brønsted and Lewis Acid Sites in Acetalization of Glycerol over Modified Mesoporous Cellular Foams. J. Phys. Chem. C 2016, 120, 16699-16711. [CrossRef]

32. Oliveira, P.A.; Souza, R.O.M.A.; Mota, C.J.A. Atmospheric Pressure Continuous Production of Solketal from the Acid-Catalyzed Reaction of Glycerol with Acetone. J. Braz. Chem. Soc. 2016, 27, 1832-1837. [CrossRef]

33. Ilgen, O.; Yerlikaya, S.; Akyurek, F.O. Synthesis of Solketal from Glycerol and Acetone over Amberlyst-46 to Produce an Oxygenated Fuel Additive. Period. Polytech. Chem. Eng. 2016, 61, 144-148. [CrossRef] 
34. Wu, L.; Moteki, T.; Gokhale, A.A.; Flaherty, D.W.; Toste, F.D. Production of Fuels and Chemicals from Biomass: Condensation Reactions and Beyond. Chem 2016, 1, 32-58. [CrossRef]

35. Yang, J.; Li, N.; Ma, W.J.; Zhou, J.H.; Sun, H.Z. Synthesis of Solketal with Catalyst Sulfonic Acid Resin. Adv. Mater. Res. 2014, 830, 176-179. [CrossRef]

36. Guidi, S.; Noe, M.; Riello, P.; Perosa, A.; Selva, M. Towards a Rational Design of a Continuous-Flow Method for the Acetalization of Crude Glycerol: Scope and Limitations of Commercial Amberlyst 36 and $\mathrm{AlF}_{3} \cdot 3 \mathrm{H}_{2} \mathrm{O}$ as Model Catalysts. Molecules 2016, 21, 657. [CrossRef]

37. Li, L.; Korányi, T.I.; Sels, B.F.; Pescarmona, P.P. Highly-efficient conversion of glycerol to solketal over heterogeneous Lewis acid catalysts. Green Chem. 2012, 14, 1611-1619. [CrossRef]

38. Abreu, T.H.; Meyer, C.I.; Padró, C.; Martins, L. Acidic V-MCM-41 catalysts for the liquid-phase ketalization of glycerol with acetone. Microporous Mesoporous Mater. 2019, 273, 219-225. [CrossRef]

39. Rodrigues, R.; Gonçalves, M.; Mandelli, D.; Pescarmona, P.P.; Carvalho, W.A. Solvent-free conversion of glycerol to solketal catalysed by activated carbons functionalised with acid groups. Catal. Sci. Technol. 2014, 4, 2293-2301. [CrossRef]

40. Nasser, G.A.; Kurniawan, T.; Tago, T.; Bakare, I.A.; Taniguchi, T.; Nakasaka, Y.; Masuda, T.; Muraza, O. Cracking of n-hexane over hierarchical MOR zeolites derived from natural minerals. J. Taiwan Inst. Chem. Eng. 2016, 61, 20-25. [CrossRef]

41. Ahmed, M.H.M.; Muraza, O.; Al-Amer, A.M.; Miyake, K.; Nishiyama, N. Development of hierarchical EU-1 zeolite by sequential alkaline and acid treatments for selective dimethyl ether to propylene (DTP). Appl. Catal. A Gen. 2015, 497, 127-134. [CrossRef]

42. Chen, L.; Nohair, B.; Zhao, D.; Kaliaguine, S. Highly Efficient Glycerol Acetalization over Supported Heteropoly Acid Catalysts. ChemCatChem 2018, 10, 1918-1925. [CrossRef]

43. Li, R.; Song, H.; Chen, J. Propylsulfonic Acid Functionalized SBA-15 Mesoporous Silica as Efficient Catalysts for the Acetalization of Glycerol. Catalysts 2018, 8, 297. [CrossRef]

44. Vicente, G.; Melero, J.A.; Morales, G.; Paniagua, M.; Martín, E. Acetalisation of bio-glycerol with acetone to produce solketal over sulfonic mesostructured silicas. Green Chem. 2010, 12, 899. [CrossRef]

45. Morales, G.; Paniagua, M.; Melero, J.A.; Vicente, G.; Ochoa, C. Sulfonic Acid-Functionalized Catalysts for the Valorization of Glycerol via Transesterification with Methyl Acetate. Ind. Eng. Chem. Res. 2011, 50, 5898-5906. [CrossRef]

46. Churipard, S.R.; Manjunathan, P.; Chandra, P.; Shanbhag, G.V.; Ravishankar, R.; Rao, P.V.C.; Sri Ganesh, G.; Halgeri, A.B.; Maradur, S.P. Remarkable catalytic activity of a sulfonated mesoporous polymer $\left(\mathrm{MP}-\mathrm{SO}_{3} \mathrm{H}\right)$ for the synthesis of solketal at room temperature. New J. Chem. 2017, 41, 5745-5751. [CrossRef]

47. Konwar, L.J.; Samikannu, A.; Mäki-Arvela, P.; Boström, D.; Mikkola, J.-P. Lignosulfonate-based macro/mesoporous solid protonic acids for acetalization of glycerol to bio-additives. Appl. Catal. B Environ. 2018, 220, 314-323. [CrossRef]

48. Nanda, M.R.; Yuan, Z.; Qin, W.; Ghaziaskar, H.S.; Poirier, M.-A.; Xu, C. A new continuous-flow process for catalytic conversion of glycerol to oxygenated fuel additive: Catalyst screening. Appl. Energy 2014, 123, 75-81. [CrossRef]

49. Mota, C.J.A.; Da Silva, C.X.A.; Rosenbach, N.; Costa, J.; Da Silva, F. Glycerin Derivatives as Fuel Additives: The Addition of Glycerol/Acetone Ketal (Solketal) in Gasolines. Energy Fuels 2010, 24, 2733-2736. [CrossRef]

50. Lin, C.-Y.; Tsai, S.-M. Comparison of Fuel Properties of Nanoemulsions of Diesel Fuel Dispersed with Solketal by Microwave Irradiation and Mechanical Homogenization Methods. Energy Fuels 2018, 32, 11814-11820. [CrossRef]

51. Esteban, J.; Murasiewicz, H.; Simons, T.A.H.; Bakalis, S.; Fryer, P.J. Measuring the Density, Viscosity, Surface Tension, and Refractive Index of Binary Mixtures of Cetane with Solketal, a Novel Fuel Additive. Energy Fuels 2016, 30, 7452-7459. [CrossRef]

52. Laskar, I.B.; Rajkumari, K.; Gupta, R.; Rokhum, L. Acid functionalized mesoporous polymer catalyzed acetalization of glycerol to solketal, a potential fuel additive under solvent-free conditions. Energy Fuels 2018, 32, 12567-12576. [CrossRef]

53. Timofeeva, M.N.; Panchenko, V.N.; Krupskaya, V.V.; Gil, A.; Vicente, M.A. Effect of nitric acid modification of montmorillonite clay on synthesis of solketal from glycerol and acetone. Catal. Commun. 2017, 90, 65-69. [CrossRef] 
54. Fatimah, I.; Wang, S.; Wulandari, D. ZnO/montmorillonite for photocatalytic and photochemical degradation of methylene blue. Appl. Clay Sci. 2011, 53, 553-560. [CrossRef]

55. Fatimah, I.; Wang, S.; Narsito; Wijaya, K. Composites of $\mathrm{TiO}_{2}$-aluminum pillared montmorillonite: Synthesis, characterization and photocatalytic degradation of methylene blue. Appl. Clay Sci. 2010, 50, 588-593. [CrossRef]

56. Fatimah, I.; Huda, T. Preparation of cetyltrimethylammonium intercalated Indonesian montmorillonite for adsorption of toluene. Appl. Clay Sci. 2013, 74, 115-120. [CrossRef]

57. Sonar, S.K.; Shinde, A.S.; Asok, A.; Niphadkar, P.S.; Mayadevi, S.; Joshi, P.N.; Bokade, V.V. Solvent free acetalization of glycerol with formaldehyde over hierarchical zeolite of BEA topology. Environ. Prog. Sustain. Energy 2018, 37, 797-807. [CrossRef]

58. Mallesham, B.; Rao, B.G.; Reddy, B.M. Production of biofuel additives by esterification and acetalization of bioglycerol. C. R. Chim. 2016, 19, 1194-1202. [CrossRef]

59. Da Silva, C.X.A.; Gonçalves, V.L.C.; Mota, C.J.A. Water-tolerant zeolitecatalyst for the acetalisation of glycerol. Green Chem. 2009, 11, 38-41. [CrossRef]

60. Sandesh, S.; Halgeri, A.B.; Shanbhag, G.V. Utilization of renewable resources: Condensation of glycerol with acetone at room temperature catalyzed by organic-inorganic hybrid catalyst. J. Mol. Catal. A Chem. 2015, 401, 73-80. [CrossRef]

61. Hasabnis, A.; Mahajani, S. Acetalization of Glycerol with Formaldehyde by Reactive Distillation. Ind. Eng. Chem. Res. 2014, 53, 12279-12287. [CrossRef]

62. Ammaji, S.; Rao, G.S.; Chary, K.V.R. Acetalization of glycerol with acetone over various metal-modified SBA-15 catalysts. Appl. Petrochem. Res. 2018, 8, 107-118. [CrossRef]

63. Dmitriev, G.S.; Terekhov, A.V.; Zanaveskin, L.N.; Khadzhiev, S.N.; Zanaveskin, K.L.; Maksimov, A.L. Choice of a catalyst and technological scheme for synthesis of solketal. Rus. J. Appl. Chem. 2017, 89, 1619-1624. [CrossRef]

64. Kowalska-Kus, J.; Held, A.; Frankowski, M.; Nowinska, K. Solketal formation from glycerol and acetone over hierarchical zeolites of different structure as catalysts. J. Mol. Catal. A Chem. 2017, 426, 205-212. [CrossRef]

65. Kowalska-Kus, J.; Held, A.; Nowinska, K. Enhancement of the catalytic activity of H-ZSM-5 zeolites for glycerol acetalization by mechanical grinding. React. Kinet. Mech. Catal. 2015, 117, 341-352. [CrossRef]

66. Ahmed, M.H.M.; Muraza, O.; Yoshioka, M.; Yokoi, T. Effect of multi-step desilication and dealumination treatments on the performance of hierarchical EU-1 zeolite for converting methanol to olefins. Microporous Mesoporous Mater. 2017, 241, 79-88. [CrossRef]

67. Muraza, O.; Bakare, I.A.; Tago, T.; Konno, H.; Taniguchi, T.; Al-Amer, A.M.; Yamani, Z.H.; Nakasaka, Y.; Masuda, T. Selective catalytic cracking of n-hexane to propylene over hierarchical MTT zeolite. Fuel 2014, 135, 105-111. [CrossRef]

68. Ahmed, M.H.M.; Muraza, O.; Nakaoka, S.; Jamil, A.K.; Mayoral, A.; Sebastian, V.; Yamani, Z.H.; Masuda, T. Stability Assessment of Regenerated Hierarchical ZSM-48 Zeolite Designed by Post-Synthesis Treatment for Catalytic Cracking of Light Naphtha. Energy Fuels 2017, 31, 14097-14103. [CrossRef]

69. Rossa, V.; Pessanha, Y.D.S.P.; Díaz, G.C.; Câmara, L.D.T.; Pergher, S.B.C.; Aranda, D.A.G. Reaction Kinetic Study of Solketal Production from Glycerol Ketalization with Acetone. Ind. Eng. Chem. Res. 2017, 56, 479-488. [CrossRef]

70. Chen, Z.; Gao, L.; Han, W.; Zhang, L. Energy and exergy analyses of coal gasification with supercritical water and $\mathrm{O}_{2}-\mathrm{H}_{2} \mathrm{O}$. Appl. Therm. Eng. 2019, 148, 57-63. [CrossRef]

71. Aghbashlo, M.; Tabatabaei, M.; Hosseinpour, S.; Rastegari, H.; Ghaziaskar, H.S. Multi-objective exergy-based optimization of continuous glycerol ketalization to synthesize solketal as a biodiesel additive in subcritical acetone. Energy Convers. Manag. 2018, 160, 251-261. [CrossRef]

72. Venkatesha, N.J.; Bhat, Y.S.; Prakash, B.S.J. Dealuminated BEA zeolite for selective synthesis of five-membered cyclic acetal from glycerol under ambient conditions. RSC Adv. 2016, 6, 18824-18833. [CrossRef]

73. Manjunathan, P.; Maradur, S.P.; Halgeri, A.B.; Shanbhag, G.V. Room temperature synthesis of solketal from acetalization of glycerol with acetone: Effect of crystallite size and the role of acidity of beta zeolite. J. Mol. Catal. A Chem. 2015, 396, 47-54. [CrossRef]

74. Aghbashlo, M.; Tabatabaei, M.; Rastegari, H.; Ghaziaskar, H.S.; Shojaei, T.R. On the exergetic optimization of solketalacetin synthesis as a green fuel additive through ketalization of glycerol-derived monoacetin with acetone. Renew. Energy 2018, 126, 242-253. [CrossRef] 
75. Gholami, A.; Hajinezhad, A.; Pourfayaz, F.; Ahmadi, M.H. The effect of hydrodynamic and ultrasonic cavitation on biodiesel production: An exergy analysis approach. Energy 2018, 160, 478-489. [CrossRef]

76. Ortiz, F.G.; Ollero, P.; Serrera, A.; Galera, S. Process integration and exergy analysis of the autothermal reforming of glycerol using supercritical water. Energy 2012, 42, 192-203. [CrossRef]

77. Ortiz, F.G.; Ollero, P.; Serrera, A.; Galera, S. An energy and exergy analysis of the supercritical water reforming of glycerol for power production. Int. J. Hydrogen Energy 2012, 37, 209-226. [CrossRef]

78. Hajjaji, N.; Baccar, I.; Pons, M.-N. Energy and exergy analysis as tools for optimization of hydrogen production by glycerol autothermal reforming. Renew. Energy 2014, 71, 368-380. [CrossRef]

79. Presciutti, A.; Asdrubali, F.; Baldinelli, G.; Rotili, A.; Malavasi, M.; Di Salvia, G. Energy and exergy analysis of glycerol combustion in an innovative flameless power plant. J. Clean. Prod. 2018, 172, 3817-3824. [CrossRef]

80. Antonova, Z.A.; Krouk, V.S.; Pilyuk, Y.E.; Maksimuk, Y.V.; Karpushenkava, L.S.; Krivova, M.G. Exergy analysis of canola-based biodiesel production in Belarus. Fuel Process. Technol. 2015, 138, 397-403. [CrossRef]

81. Ahmed, M.H.M.; Muraza, O.; Galadima, A.; Yoshioka, M.; Yamani, Z.H.; Yokoi, T. Choreographing boron-aluminum acidity and hierarchical porosity in *BEA zeolite by in-situ hydrothermal synthesis for a highly selective methanol to propylene catalyst. Microporous Mesoporous Mater. 2019, 273, 249-255. [CrossRef]

82. Galadima, A.; Muraza, O. Hydrocracking catalysts based on hierarchical zeolites: A recent progress. J. Ind. Eng. Chem. 2018, 61, 265-280. [CrossRef]

83. Yang, X.; Wang, F.; Wei, R.; Li, S.; Wu, Y.; Shen, P.; Wang, H.; Gao, L.; Xiao, G. Synergy effect between hierarchical structured and Sn-modified H[Sn, Al]ZSM-5 zeolites on the catalysts for glycerol aromatization. Microporous Mesoporous Mater. 2018, 257, 154-161. [CrossRef]

84. Feliczak-Guzik, A. Hierarchical zeolites: Synthesis and catalytic properties. Microporous Mesoporous Mater. 2018, 259, 33-45. [CrossRef]

85. Possato, L.G.; Chaves, T.F.; Cassinelli, W.H.; Pulcinelli, S.H.; Santilli, C.V.; Martins, L. The multiple benefits of glycerol conversion to acrolein and acrylic acid catalyzed by vanadium oxides supported on micro-mesoporous MFI zeolites. Catal. Today 2017, 289, 20-28. [CrossRef]

86. Huang, G.; Ji, P.; Xu, H.; Jiang, J.-G.; Chen, L.; Wu, P. Fast synthesis of hierarchical Beta zeolites with uniform nanocrystals from layered silicate precursor. Microporous Mesoporous Mater. 2017, 248, 30-39. [CrossRef]

87. Yu, Q.; Cui, C.; Zhang, Q.; Chen, J.; Li, Y.; Sun, J.; Li, C.; Cui, Q.; Yang, C.; Shan, H. Hierarchical ZSM-11 with intergrowth structures: Synthesis, characterization and catalytic properties. J. Energy Chem. 2013, 22, 761-768. [CrossRef]

88. Galadima, A.; Muraza, O. In situ fast pyrolysis of biomass with zeolite catalysts for bioaromatics/gasoline production: A review. Energy Convers. Manag. 2015, 105, 338-354. [CrossRef]

89. Bawah, A.-R.; Malaibari, Z.O.; Muraza, O. Syngas production from $\mathrm{CO}_{2}$ reforming of methane over Ni supported on hierarchical silicalite-1 fabricated by microwave-assisted hydrothermal synthesis. Int. J. Hydrogen Energy 2018, 43, 13177-13189. [CrossRef]

90. Muraza, O.; Bakare, I.A.; Tago, T.; Konno, H.; Adedigba, A.-L.; Al-Amer, A.M.; Yamani, Z.H.; Masuda, T. Controlled and rapid growth of MTT zeolite crystals with low-aspect-ratio in a microwave reactor. Chem. Eng. J. 2013, 226, 367-376. [CrossRef]

91. El Hanache, L.; Lebeau, B.; Nouali, H.; Toufaily, J.; Hamieh, T.; Daou, T.J. Performance of surfactant-modified *BEA-type zeolite nanosponges for the removal of nitrate in contaminated water: Effect of the external surface. J. Hazard. Mater. 2019, 364, 206-217. [CrossRef] [PubMed]

92. Sammoury, H.; Toufaily, J.; Cherry, K.; Hamieh, T.; Pouilloux, Y.; Pinard, L. Desilication of *BEA zeolites using different alkaline media: Impact on catalytic cracking of n-hexane. Microporous Mesoporous Mater. 2018, 267, 150-163. [CrossRef]

93. Gonçalves, M.; Rodrigues, R.; Galhardo, T.S.; Carvalho, W.A. Highly selective acetalization of glycerol with acetone to solketal over acidic carbon-based catalysts from biodiesel waste. Fuel 2016, 181, 46-54. [CrossRef]

94. Li, Z.; Miao, Z.; Wang, X.; Zhao, J.; Zhou, J.; Si, W.; Zhuo, S. One-pot synthesis of ZrMo-KIT-6 solid acid catalyst for solvent-free conversion of glycerol to solketal. Fuel 2018, 233, 377-387. [CrossRef]

95. Liu, J.; Li, Y.; Liu, H.; He, D. Transformation of $\mathrm{CO}_{2}$ and glycerol to glycerol carbonate over $\mathrm{CeO}_{2} \mathrm{ZrO}_{2}$ solid solution-Effect of Zr doping. Biomass Bioenergy 2018, 118, 74-83. [CrossRef]

96. Malaika, A.; Kozłowski, M. Glycerol conversion towards valuable fuel blending compounds with the assistance of $\mathrm{SO}_{3} \mathrm{H}$-functionalized carbon xerogels and spheres. Fuel Process. Technol. 2019, 184, 19-26. [CrossRef] 
97. Wan, Y.; Lei, Y.; Lan, G.; Liu, D.; Li, G.; Bai, R. Synthesis of glycerol carbonate from glycerol and dimethyl carbonate over DABCO embedded porous organic polymer as a bifunctional and robust catalyst. Appl. Catal. A Gen. 2018, 562, 267-275. [CrossRef]

98. Oger, N.; Lin, Y.F.; Le Grognec, E.; Rataboul, F.; Felpin, F.-X. Graphene-promoted acetalisation of glycerol under acid-free conditions. Green Chem. 2016, 18, 1531-1537. [CrossRef]

99. Nandan, D.; Sreenivasulu, P.; Konathala, L.S.; Kumar, M.; Viswanadham, N. Acid functionalized carbon-silica composite and its application for solketal production. Microporous Mesoporous Mater. 2013, 179, 182-190. [CrossRef]

100. Khayoon, M.S.; Hameed, B.H. Solventless acetalization of glycerol with acetone to fuel oxygenates over $\mathrm{Ni}-\mathrm{Zr}$ supported on mesoporous activated carbon catalyst. Appl. Catal. A Gen. 2013, 464, 191-199. [CrossRef]

101. Talebian-Kiakalaieh, A.; Amin, N.A.S.; Rajaei, K.; Tarighi, S. Oxidation of bio-renewable glycerol to value-added chemicals through catalytic and electro-chemical processes. Appl. Energy 2018, 230, 1347-1379. [CrossRef]

102. Chol, C.G.; Dhabhai, R.; Dalai, A.K.; Reaney, M. Purification of crude glycerol derived from biodiesel production process: Experimental studies and techno-economic analyses. Fuel Process. Technol. 2018, 178, 78-87. [CrossRef]

103. Ismail, M.S.; Moghavvemi, M.; Mahlia, T.M.I. Techno-economic analysis of an optimized photovoltaic and diesel generator hybrid power system for remote houses in a tropical climate. Energy Convers. Manag. 2013, 69, 163-173. [CrossRef]

104. Fantozzi, F.; Frassoldati, A.; Bartocci, P.; Cinti, G.; Quagliarini, F.; Bidini, G.; Ranzi, E.M. An experimental and kinetic modeling study of glycerol pyrolysis. Appl. Energy 2016, 184, 68-76. [CrossRef]

105. Norhasyima, R.S.; Mahlia, T.M.I. Advances in $\mathrm{CO}_{2}$ utilization technology: A patent landscape review. J. CO2 Util. 2018, 26, 323-335. [CrossRef]

106. Eze, V.C.; Harvey, A.P. Continuous reactive coupling of glycerol and acetone-A strategy for triglyceride transesterification and in-situ valorisation of glycerol by-product. Chem. Eng. J. 2018, 347, 41-51. [CrossRef]

107. Jamil, F.; Saxena, S.K.; Al-Muhtaseb, A.A.H.; Baawain, M.; Al-Abri, M.; Viswanadham, N.; Kumar, G.; Abu-Jrai, A.M. Valorization of waste "date seeds" bio-glycerol for synthesizing oxidative green fuel additive. J. Clean. Prod. 2017, 165, 1090-1096. [CrossRef]

108. Priya, S.S.; Selvakannan, P.R.; Chary, K.V.R.; Kantam, M.L.; Bhargava, S.K. Solvent-free microwave-assisted synthesis of solketal from glycerol using transition metal ions promoted mordenite solid acid catalysts. Mol. Catal. 2017, 434, 184-193. [CrossRef]

109. Trifoi, A.R.; Agachi, P.Ş.; Pap, T. Glycerol acetals and ketals as possible diesel additives. A review of their synthesis protocols. Renew. Sustain. Energy Rev. 2016, 62, 804-814. [CrossRef]

110. Remón, J.; Ruiz, J.; Oliva, M.; García, L.; Arauzo, J. Effect of biodiesel-derived impurities (acetic acid, methanol and potassium hydroxide) on the aqueous phase reforming of glycerol. Chem. Eng. J. 2016, 299, 431-448. [CrossRef]

(C) 2019 by the authors. Licensee MDPI, Basel, Switzerland. This article is an open access article distributed under the terms and conditions of the Creative Commons Attribution (CC BY) license (http://creativecommons.org/licenses/by/4.0/). 